\title{
Manifestations of the viability (resilience) of parents raising children with disabilities
}

\author{
Elena Tkach ${ }^{1, *}$, Elisa Nazareth Mendoza Ortega ${ }^{1}$ \\ ${ }^{1}$ Pacific National University, Khabarovsk, Russia
}

\begin{abstract}
The paper presents the results of an empirical study of the viability, hardiness and life satisfaction index of parents raising children with disabilities in Khabarovsk city, Russian Federation. According to the results of the study, parents who raise children with disabilities show deteriorated performance on all tests. As a result of the analysis on the viability tests and the "life satisfaction index", statistically significant differences were revealed between the two groups of the sample; on the hardiness test, such differences were shown only on one of the scales. It was found that viability for parents of children with disabilities is not a full resource. The study confirmed the key role of the indicator "meaningfulness of life" as a "vertical" factor of viability. According to the data obtained using the "Life satisfaction index" test, the most powerful influence on the value of the life satisfaction index of parents raising children with disabilities is provided by indicators of consistency between goals set and achieved and the general mood background. In addition, these indicators also strongly correlate with each other. The results of the study showed that both groups of parents who participated in the study demonstrated sufficient ability to withstand a stressful situation. Parents raising children with disabilities have a low value of the indicator "control" as an emotional and volitional element of the scale.
\end{abstract}

\section{Introduction}

Viability (resilience) is a rather complex and multi-faceted psychological phenomenon, there are a large number of different definitions of this phenomenon, its key correlates and characteristics. Viability has been studied by Russian scientists: Vasilyeva S. N., Rylskaya E. A. [1], Dikaya L. G., Makhnach A.V., Laktionova A. I. [2], Makhnach A.V. [3, 4, 5, 6], and also by foreign scientists: Brigid Daniel etc. [7], Makhnach A.V. [8], Zautra A.J., Hall J.S., Murray K.E. [9], Fletcher, D., Sarkar, M. [10], Hjemdal, O. etc. [11], Letzring, T.D [12], Salisu I., Hashim N.A [13], Smith,W.J.[14], Strnadova, I.[15], Windle G. etc. [16]. Despite the majority of scientists' acceptance of the problem of viability (risk, protective factors, adverse circumstances), it is obvious that the context, the nature of adverse circumstances, and the time factor play an important role in the manifestation of viability. Based on this, we can conclude that there is no single measurement scale that is suitable for all research purposes of measuring resilience and cannot exist. The empirical research

\footnotetext{
* Corresponding author: elenat3004@mail.ru
} 
presented in this paper is devoted to identifying the features of the manifestation of the viability of parents raising children with disabilities.

\section{Main part}

The purpose of this study is to identify and describe the manifestations of viability (resilience) of parents raising children with disabilities.

The objectives of the study were as follows:

- to compare statistically the level of viability of parents of children with disabilities with the level of viability of parents of neurotypical children (without disabilities);

- to consider the differences in the components of viability between these groups;

- to compare the quantitative results obtained using the viability test and methods for assessing hardiness and the life satisfaction index.

E. A. Rylskaya's method (human viability test), well described and documented in her doctoral dissertation, was chosen as the main diagnostic tool for measuring viability. This test was developed by a Russian specialist based on the study of foreign experience specifically for Russia, passed here all the necessary procedures for checking reliability and validation, and is highly appreciated by domestic scientists (including A.V. Makhnach, A. A. Nesterova, etc.).

In addition to conducting the main viability test, it was also decided to evaluate the indicator of hardiness, as an indicator of personality that characterizes resistance to stress and the life satisfaction index (LSI), which expresses the overall attitude of a person to life. The complex application of these methods allows us to give, in our opinion, a fairly reliable assessment of the viability of parents raising children with disabilities in comparison with their hardiness and overall life satisfaction.

In the course of the empirical study, 40 people were interviewed in Khabarovsk city, Russian Federation. Two groups of parents were studied: parents of children with disabilities and parents of neurotypical children. The size of each sample was determined to be 20 people. The average age of the survey participants was 38 years, the majority of the total number has a higher education $(75 \%)$, it should be noted that $75 \%$ of the respondents are women.

The survey of parents of children with disabilities was conducted with the help and support of psychologists of "Regional State Educational Institution "Secondary school No 5" and "Regional State State-owned Educational Institution of Primary Vocational Education "Vocational school No 6" in the city of Khabarovsk. Children of the surveyed parents in this group suffer from such diseases as: autism spectrum disorders, delayed mental and speech development, Down's syndrome, organic brain damage, schizophrenia, epilepsy. Parents of neurotypical children were selected randomly.

\section{Results of the study}

According to the data obtained using the E. A. Rylskaya viability test, parents of children with disabilities showed a low value of resilience. For parents of neurotypical children, the average value of resilience was relevant. Individual values of the integral resilience index which are below the average level reflect the presence of serious difficulties in adapting to the adverse circumstances in which these people find themselves. This can be expressed in passivity, lack of flexibility to respond to changing conditions, problems in the workplace, problems in the family, lack of self-confidence and confidence in the future. It can also indicate dissatisfaction with your life, lack of interest and meaning in life, a sense of hopelessness and helplessness. 
To check the statistical significance of differences between samples, the Mann-Whitney U-test was used.

Table 1. Differences between sampling scales.

\begin{tabular}{|c|c|c|c|c|c|}
\hline & $\begin{array}{c}\text { Ability to } \\
\text { adapt }\end{array}$ & $\begin{array}{c}\text { Ability to } \\
\text { self-regulate }\end{array}$ & $\begin{array}{c}\text { Ability to } \\
\text { self-develop }\end{array}$ & Meaningfulness & Viability \\
\hline $\begin{array}{c}\text { U fact Mann- } \\
\text { Whitney }\end{array}$ & 53.5 & 129 & 58 & 100.5 & 230 \\
\hline $\begin{array}{c}\text { U test Mann- } \\
\text { Whitney } \\
\text { at } \alpha=0.05, \mathrm{n}=20\end{array}$ & 127 & 127 & 127 & 127 & 127 \\
\hline $\begin{array}{c}\text { Significance of } \\
\text { sample differences }\end{array}$ & yes & no & yes & yes & yes \\
\hline
\end{tabular}

Based on the analysis, we can conclude that the first sample (parents of children with disabilities) has statistically significant differences in comparison with the second sample (parents of neurotypical children) both for the integral indicator and for the indicators of individual scales, except for the scale of self-regulation ability.

It is interesting to assess how different components of resilience interact in comparison between samples. This analysis was carried out using correlation analysis - the interaction of components and an integral indicator with the verification of statistical significance based on the Student's criterion.

Table 2. Correlation in the sample of parents raising children with disabilities.

\begin{tabular}{|c|c|c|c|l|l|}
\hline Components & $\begin{array}{c}\text { Ability to } \\
\text { adapt }\end{array}$ & $\begin{array}{c}\text { Ability to } \\
\text { self-regulate }\end{array}$ & $\begin{array}{c}\text { Ability to } \\
\text { self- } \\
\text { develop }\end{array}$ & Meaningfulness & Resilience \\
\hline Ability to adapt & 1 & 1 & & & \\
\hline $\begin{array}{c}\text { Ability to self- } \\
\text { regulate }\end{array}$ & $-0.35^{*}$ & 0.06 & 1.00 & & \\
\hline $\begin{array}{c}\text { Ability to self- } \\
\text { develop }\end{array}$ & -0.03 & 0.15 & 0.03 & 1.00 & 1 \\
\hline $\begin{array}{c}\text { Meaningfulness } \\
\text { Resilience }\end{array}-0.17$ & $0.39 *$ & $0.42^{* *}$ & $0.47^{* *}$ & $0.53^{* * *}$ & \\
\hline significance level: $* 0.05^{* *} 0.01 * * * 0,001$ & & \\
\hline
\end{tabular}

When considering the obtained correlation results, it can be noted that the integral resilience index is not reduced to a simple sum of its components, but provides a new synergistic effect that exceeds the effect of each of these elements. So, the most powerful influence on the value of resilience is shown by the scale of meaningfulness of life $(0.53$ with a significance of 0.001). There is a negative relationship between the ability to adapt and the ability to self-regulate $(-0.35)$. Perhaps the negative relationship suggests that at low levels of adaptation and self-regulation, people prefer to make the choice "or" - "or", to avoid solving the issue or to pass it on to others. 
The weak relationship between ability to adapt and resilience (0.39), in our opinion, may indicate that parents do not use resilience as a resource, preferring to adapt to changes, without too much hope for the best and without making efforts to change.

In general, it can be assumed that, since parents raising children with disabilities are characterized by low values for each of the ability scales, the influence of each of them on the integral indicator is also from weak to average at best.

For comparison, we consider the obtained correlations in a sample of parents raising children who do not suffer from health restrictions.

Table 3. Correlation in the sample of parents raising neurotypical children.

\begin{tabular}{|c|c|c|c|c|c|}
\hline Components & $\begin{array}{c}\text { Ability to } \\
\text { adapt }\end{array}$ & $\begin{array}{c}\text { Ability to } \\
\text { self-regulate }\end{array}$ & $\begin{array}{l}\text { Ability to } \\
\text { self-develop }\end{array}$ & Meaningfulness & Resilience \\
\hline Ability to adapt & 1 & & & & \\
\hline $\begin{array}{l}\text { Ability to self- } \\
\text { regulate }\end{array}$ & -0.07 & 1.00 & & & \\
\hline $\begin{array}{l}\text { Ability to self- } \\
\text { develop }\end{array}$ & 0.14 & $0.55^{* * *}$ & 1.00 & & \\
\hline Meaningfulness & 0.28 & $0.50 * *$ & 0.24 & 1.00 & \\
\hline Resilience & $0.69 * * *$ & $0.61 * * *$ & $0.60 * * *$ & $0.71 * * *$ & 1 \\
\hline
\end{tabular}

This table shows that the interdependence of the components and the integral indicator is much stronger, in most cases it corresponds to the average level of correlation, and for the component "meaningfulness of life" - a strong level with a significance level of 0.001 according to the Student's criterion. Also noteworthy is the absence of a correlation between ability to self-regulate and adaptation, ability to self-develop and adaptation, meaningfulness of life and adaptation, meaningfulness of life and ability to self-develop.

In general, the analysis of the correlation of resilience components for two samples showed that the integral indicator increases its systemic effect if the quantitative expression of individual components is sufficiently high and increases even more if these values increase.

Parents who belong to different samples also perceive and evaluate their family's resources differently. Resilience for parents of children with disabilities is not a full resource, in any case, there is a weak or even absent relationship between resilience and components. Parents included in the second sample with a higher integral indicator use resilience more effectively as a psychological resource, in addition, their individual skills allow them to make a greater contribution to family resourcefulness.

According to the results of correlation analysis, the most important component that affects resilience is the "meaningfulness of life" component. The ability to make sense of life allows people to extract meanings and essences, better understand what is happening, develop constructively, and build their own life world.

The obtained results of the correlation analysis for the component "meaningfulness of life" (for 1 and 2 samples the correlation coefficients 0.53 and 0.71 with the significance level according to the Student's criterion of 0.001 ) are consistent with the conclusion that meaningfulness of life is the determining component of resilience, the growth of which determines the severity of all other components. 
According to the results of the life satisfaction test (adaptation by N. V. Panina), parents of children with disabilities showed life satisfaction below the overall average value, and parents of neurotypical children showed an average level of expression of the life satisfaction index.

The low individual value of the life satisfaction index for parents raising children with health disorders can be explained by the fact that these people are trying to deal with a difficult and unfavorable life situation, which leads to a shift in attention and rejection of selfactualization, their own success, some personal small plans, desires, hopes and prospects. Naturally, this leads to a decrease in the sense of life satisfaction.

To check the statistical significance of differences between samples, the Mann-Whitney U-test was used.

Table 4. Check the differences between sampling scales.

\begin{tabular}{|c|c|c|c|c|c|c|}
\hline Indicator & $\begin{array}{l}\text { Interes } \\
t \text { in life }\end{array}$ & $\begin{array}{c}\text { The } \\
\text { sequence } \\
\text { in } \\
\text { achievin } \\
\text { g the } \\
\text { objective } \\
\text { s }\end{array}$ & $\begin{array}{c}\text { Consistenc } \\
\text { y between } \\
\text { goals set } \\
\text { and } \\
\text { achieved }\end{array}$ & $\begin{array}{c}\text { Positive } \\
\text { assessmen } \\
\text { t of } \\
\text { yourself } \\
\text { and your } \\
\text { own } \\
\text { actions }\end{array}$ & $\begin{array}{c}\text { The } \\
\text { general } \\
\text { mood } \\
\text { backgroun } \\
\text { d }\end{array}$ & $\begin{array}{c}\text { LS } \\
\text { I }\end{array}$ \\
\hline $\begin{array}{l}U \text { fact } \\
\text { Mann- } \\
\text { Whitney }\end{array}$ & 160.5 & 147.5 & 119.5 & 170.5 & 152 & 119 \\
\hline $\begin{array}{l}U \text { test } \\
\text { Mann- } \\
\text { Whitney } \\
\text { at } \alpha=0.05 \text {, } \\
\mathrm{n}=20\end{array}$ & 127 & 127 & 127 & 127 & 127 & 127 \\
\hline $\begin{array}{l}\text { Significanc } \\
\text { e of sample } \\
\text { differences }\end{array}$ & No & No & Yes & No & No & Yes \\
\hline
\end{tabular}

Based on the analysis, it can be concluded that the first sample (parents of children with developmental disabilities) has statistically significant differences in comparison with the second sample (parents of children with normal developmental disabilities) on the life satisfaction index and on the scale of consistency of goals set and achieved, but such differences are not confirmed by the indicators of the other scales.

A possible explanation for this, in our opinion, may be the fact that even in spite of difficult life circumstances, certain factors must remain at some necessary level to maintain normal life activity. In particular, positive self-esteem should be present as an understanding that parents can and should support their children with disabilities. At the same time, the test showed a difference on the consistency scale between the goals set and achieved, as well as directly on the index itself - which indicates that this integral indicator also shows a system property that is not reduced to a simple sum of its components.

To assess the interaction of various components of the life satisfaction index in comparison between the samples, a correlation analysis was performed. 
Table 5. Correlation in the sample of parents raising children with disabilities.

\begin{tabular}{|c|c|c|c|c|c|c|}
\hline Indicator & $\begin{array}{l}\text { Interes } \\
t \text { in life }\end{array}$ & $\begin{array}{l}\text { The } \\
\text { sequence } \\
\text { in } \\
\text { achievin } \\
\text { g the } \\
\text { objective } \\
\text { s }\end{array}$ & $\begin{array}{l}\text { Consistenc } \\
\text { y between } \\
\text { goals set } \\
\text { and } \\
\text { achieved }\end{array}$ & $\begin{array}{l}\text { Positive } \\
\text { assessmen } \\
t \quad \text { of } \\
\text { yourself } \\
\text { and your } \\
\text { own } \\
\text { actions }\end{array}$ & $\begin{array}{l}\text { The } \\
\text { general } \\
\text { mood } \\
\text { backgroun } \\
\text { d }\end{array}$ & $\begin{array}{l}\text { LS } \\
\text { I }\end{array}$ \\
\hline $\begin{array}{l}\text { Interest in } \\
\text { life }\end{array}$ & 1 & & & & & \\
\hline $\begin{array}{l}\text { The } \\
\text { sequence } \\
\text { in } \\
\text { achieving } \\
\text { the } \\
\text { objectives }\end{array}$ & -0.09 & 1 & & & & \\
\hline $\begin{array}{l}\text { Consistenc } \\
\text { y between } \\
\text { goals set } \\
\text { and } \\
\text { achieved }\end{array}$ & 0.24 & $0.46^{* *}$ & 1 & & & \\
\hline $\begin{array}{l}\text { Positive } \\
\text { assessment } \\
\text { of yourself } \\
\text { and your } \\
\text { own } \\
\text { actions }\end{array}$ & 0.3 & 0.18 & $0.51 * * *$ & 1 & & \\
\hline $\begin{array}{l}\text { The } \\
\text { general } \\
\text { mood } \\
\text { backgroun } \\
\text { d }\end{array}$ & 0.31 & $0.39 *$ & $0.82 * * *$ & $0.38 *$ & 1 & \\
\hline LSI & $0.49^{* *}$ & $0.53 * * *$ & $0.88 * * *$ & $0.69 * * *$ & $0.85^{* * *}$ & 1 \\
\hline
\end{tabular}

When considering the obtained correlation results, it can be noted that the strongest influence on the value of the life satisfaction index for parents raising children with disabilities is exerted by indicators of consistency between goals set and achieved and the general mood background ( 0.88 and 0.85 , respectively, with a significance of 0.001 ). However, these indicators are also strongly related $(0.82)$. To a much lesser extent are important indicators of interest in life and the sequence in achieving the objectives (low or medium level of correlation). It seems that this is a direct consequence of the difficult life situation in which such parents find themselves, the feeling of powerlessness and inability to achieve their goals makes it impossible in principle to achieve a high life satisfaction index.

The following table shows the correlation values between the components of the life satisfaction index for a sample of parents raising children who do not suffer from health restrictions. 
Table 6. Correlation in the sample of parents raising neurotypical children.

\begin{tabular}{|c|c|c|c|c|c|c|}
\hline Indicator & $\begin{array}{l}\text { Interes } \\
t \text { in life }\end{array}$ & $\begin{array}{c}\text { The } \\
\text { sequence } \\
\text { in } \\
\text { achievin } \\
\text { g the } \\
\text { objective } \\
\text { s }\end{array}$ & $\begin{array}{c}\text { Consistenc } \\
\text { y between } \\
\text { goals set } \\
\text { and } \\
\text { achieved }\end{array}$ & $\begin{array}{c}\text { Positive } \\
\text { assessmen } \\
\text { t of } \\
\text { yourself } \\
\text { and your } \\
\text { own } \\
\text { actions }\end{array}$ & $\begin{array}{c}\text { The } \\
\text { general } \\
\text { mood } \\
\text { backgroun } \\
\text { d }\end{array}$ & $\begin{array}{c}\text { LS } \\
\text { I }\end{array}$ \\
\hline $\begin{array}{l}\text { Interest in } \\
\text { life }\end{array}$ & 1 & & & & & \\
\hline $\begin{array}{l}\text { The } \\
\text { sequence } \\
\text { in } \\
\text { achieving } \\
\text { the } \\
\text { objectives }\end{array}$ & 0.26 & 1 & & & & \\
\hline $\begin{array}{l}\text { Consistenc } \\
\text { y between } \\
\text { goals set } \\
\text { and } \\
\text { achieved }\end{array}$ & $0.44 * *$ & $0.48 * *$ & 1 & & & \\
\hline $\begin{array}{l}\text { Positive } \\
\text { assessment } \\
\text { of yourself } \\
\text { and your } \\
\text { own } \\
\text { actions }\end{array}$ & $0.61 * * *$ & $0.54 * * *$ & $0.75^{* * *}$ & 1 & & \\
\hline $\begin{array}{l}\text { The } \\
\text { general } \\
\text { mood } \\
\text { backgroun } \\
\text { d }\end{array}$ & $0.58 * * *$ & 0.27 & $0.48 * *$ & $0.70 * * *$ & 1 & \\
\hline LSI & $0.77 * * *$ & $0.63 * * *$ & $0.80^{* * *}$ & $0.92 * * *$ & $0.77 * * *$ & 1 \\
\hline
\end{tabular}

This table shows that the interdependence of the components and the integral indicator is much stronger than in the previous case, while the most powerful factor of the index is a positive assessment of oneself and one's actions. This factor is a resource that is necessary for parents raising children with disabilities.

Also, in contrast to the other sample, parents raising children without developmental disorders have higher values of correlation of indicators, we observe that with increasing severity of signs, their impact on the overall level of life satisfaction increases and manifests itself.

The results of diagnostics carried out using the hardiness test showed that parents of children with disabilities have a lower than average level of hardiness. At the same time, there was an excess of the average level on the "risk acceptance" scale. Perhaps this circumstance is due to the fact that parents are ready to make any effort for their child, that they feel insecure, vulnerable to their situation and are therefore willing to take risks. 
Parents of neurotypical children were found to have a higher-than-average level of hardness.

The low individual value of hardness in the sample of parents of children with disabilities is associated with insufficient values on the scales of involvement and control. Involvement is manifested as a person's appeal to their values, goals, family and others, also representing involvement in what is happening around them (events, phenomena, relationships, etc.). Low value of involvement may indicate a lack of interest in what is happening in the outside world. In addition, a low value of the "control" scale may reflect a lack of confidence that something can be changed, changed for the better.

To check the statistical significance of differences between samples, the Mann-Whitney U-test was used.

Table 7. Check the differences between sampling scales.

\begin{tabular}{|l|c|c|c|c|}
\hline \multicolumn{1}{|c|}{ Indicators } & Involvement & Control & $\begin{array}{c}\text { Risk } \\
\text { acceptance }\end{array}$ & Hardness \\
\hline U fact Mann-Whitney & 167.5 & 118.5 & 178 & 146 \\
\hline $\begin{array}{l}\text { U test Mann-Whitney } \\
\text { at } \alpha=0.05\end{array}$ & 127 & 127 & 127 & 127 \\
\hline $\begin{array}{l}\text { Significance of sample } \\
\text { differences }\end{array}$ & No & Yes & No & No \\
\hline
\end{tabular}

Based on the analysis, it can be concluded that the first sample (parents of children with developmental disabilities) has no statistically significant differences in the indicator of hardness and scales of control and involvement compared to the second sample (parents of children with normal developmental disabilities). Attention is drawn to the presence of such statistically significant differences in relation to the indicator "control". This circumstance highlights the difference in living conditions between groups.

Describing the obtained indicators for the conducted tests we can note the following:

- parents raising children with disabilities show deteriorated performance on all tests;

- as a result of the analysis on the viability tests and the "life satisfaction index", statistically significant differences were revealed between the two groups of the sample; on the hardness test, such differences were shown only on one of the scales;

- according to the viability test of E. A. Rylskaya, it can be concluded that resilience for parents of children with disabilities is not a full resource, there is a weak or even absent relationship between resilience and components. This confirms the key role of the indicator "meaningfulness of life" as a "vertical" factor of resilience;

- according to the "Life satisfaction index" test, the most powerful influence on the index value for parents raising children with disabilities is provided by indicators of consistency between goals set and achieved and the general mood background. In addition these indicators also strongly correlate with each other;

- according to the hardness test, it was noted that both groups participating in the study demonstrated sufficient ability to withstand a stressful situation. Parents raising children with disabilities have a low value of the indicator "control" as an emotional and volitional element of the scale.

In order to determine the consistency of the results, it is advisable to conduct a correlation analysis of integral indicators for tests. 
Table 8. Correlation between integral indicators for tests.

\begin{tabular}{|l|c|c|c|}
\hline & Viability & LSI & Hardness \\
\hline Viability & 1 & & \\
\hline LSI & $0.32 *$ & 1 & 1 \\
\hline Hardness & $0.52 * * *$ & $0.53 * * *$ & \\
\hline significance level $* 0.05 * 0.01 * * * 0,001$ & \\
\hline
\end{tabular}

Calculations confirm the existence of correlations between the integral indicators for all tests, including the tests "hardness" and "viability", "hardness" and "life satisfaction index" with the level of significance. The absence of a strong correlation can be explained, among other things, by the fact that these methods are used to measure, although related, but different psychological constructs.

\section{Conclusions}

Viability (resilience) can be considered as a resource for positive adaptation in spite of unfavorable conditions and/or dangerous circumstances. At the same time, resilience is characterized by a combination of social and intrapsychic processes that allow a person to be healthy in an unfavorable environment.

The presence of a child with disabilities is a powerful stressor for his parents, leading to a serious violation of adaptation.

The ability of families and parents raising children with disabilities to cope with an unfavorable life situation is affected by many factors at many levels, including: government policy in relation to this category of people, the media, public sentiment, school, social institutions, interaction with the external environment, family dynamics and resources of viability, stress factors, social and economic characteristics of the family.

In the conducted empirical study, data were obtained on the levels of viability, hardness and life satisfaction index of parents raising children with disabilities in Khabarovsk city.

It should be noted that in psychological practice, in a situation where there is a child with disabilities in the family, all attention and care is paid to him. It is important to understand that such parents need psychological help focused on the development of their viability. Providing them with specially organized psychological assistance could make their lives better, and at the same time improve the life of their child, who suffers from limited health opportunities.

\section{References}

1. S.N. Vasilyeva, E.A. Rylskaya, Yaroslavl pedagogical Bulletin 2(107), 106-113 (2019) DOI: $10.24411 / 1813-145 \mathrm{X}-2019-10358$

2. L.G. Dikaya, A.V. Makhnach, A.I. Laktionova, Social and human Sciences in the Far East 15(4), 137-146 (2018) DOI: 10.31079/1992-2868-2018-15-4-137-146

3. A.V. Makhnach, Psychological journal 38(4), 5-16 (2017) DOI: 10.7868/S0205959217040018

4. A.V. Makhnach, Bulletin of Russian State University for the Humanities. Series: Psychology. Pedagogy. Education 2, 37-50 (2019) DOI: 10.28995/2073-6398-2019-2$37-50$ 
5. A.V. Makhnach, Bulletin of Kostroma State University. Series: Pedagogy. Psychology. Sociokenetics 25(2), 46-51 (2019) DOI: 10.34216/2073-1426-2019-25-2-46-51

6. A.V. Makhnach, A.I. Laktionova, Y.V. Postylyakova, Social and humanitarian sciences in the Far East 15(4), 45-54 (2018) DOI: 10.31079/1992-2868-2018-15-4-45-54

7. B. Daniel, S. Vincent, E. Farrall, F. Arney, International Journal of Child \& Family Welfare 1, 2-21 (2009) https://www.researchgate.net/publication/228500464_How_is_the_Concept_of_Resilie nce_Operationalised_in_Practice_with_Vulnerable_Children

8. A.V. , International Journal Of Adolescence And Youth 21(2), 195-214 (2016) DOI: $10.1080 / 02673843.2013 .815116$

9. A.J. Zautra, J.S. Hall, K.E. Murray, Resilience: A new definition of health for people and communities. Handbook of Adult Resilience (Guilford Press, New York, London, 2010) https://www.researchgate.net/publication/232581337_Resilience_A_new_definition_of _health_for_people_and_communities

10. D. Fletcher, M. Sarkar, European Psychologist 18, 12-23 (2013) DOI: 10.1027/10169040/a000124

11. O. Hjemdal, O. Friborg, S. Braun, P. Fossion, International Journal of Testing 11, 5370 (2011) DOI: 10.1080/15305058.2010.508570

12. T.D. Letzring, J. Block, D.C. Funder, Journal of Research in Personality 39, 395-422 (2005) DOI: 10.1016/j.jrp.2004.06.003

13. I. Salisu, N. Hashim, IOSR Journal of Business and Management (IOSR-JBM) 19(4), 23-33 (2017) DOI: 10.9790/487X-1904032333

14. W.J. Smith, International Journal of Behavioral Medicine 15, 194-200 (2008) DOI: $10.1080 / 10705500802222972$

15. I. Strnadova, Revista Complutense de Educación 17(2), 35-50 (2006) https://www.researchgate.net/publication/27592918_Stress_and_resilience_in_families _of_children_with_specific_learning_disabilities

16. G. Windle, D.A. Markland, R.T. Woods, Aging and Mental Health 12(3), 285-292 (2008) DOI: 10.1080/13607860802120763 